\title{
PENGARUH KONSELING KELOMPOK DENGAN PENDEKATAN BEHAVIOUR TERHADAP PERUBAHAN PERILAKU AGRESIF SISWA
}

\author{
Vhiolita Rohma Yaudiatama, Indarti Endang M., Panggih Wahyu Nugroho \\ Program Studi Bimbingan dan Konseling, Universitas Veteran Bangun Nusantara \\ Email: violita247@gmail.com
}

\begin{tabular}{|c|c|}
\hline Article Info & Abstrak \\
\hline $\begin{array}{l}\text { Available online } \\
\text { 15.06.2019 }\end{array}$ & $\begin{array}{l}\text { Penelitian ini bertujuan untuk mengetahui pengaruh konseling kelompok dengan pendekatan } \\
\text { behaviour terhadap perubahan perilaku agresif siswa. Dalam penelitian ini menggunakan metode } \\
\text { eksperimen pre test-post test one group design yaitu pendekatan yang diberikan pada satu } \\
\text { kelompok saja tanpa kelompok pembanding. Metode pengumpulan data dalam penelitian ini } \\
\text { dengan menggunakan skala psikologi (angket) yang disusun untuk mengungkap perilaku agresif. } \\
\text { Sedangkan metode analisis data menggunakan analisis statistik Uji Wilcoxon. Hasil penelitian } \\
\text { menunjukkan bahwa terdapat penurunan dari } 68,62 \% \text { menjadi } 56,46 \% \text { sehingga pada siswa yang } \\
\text { belum diberi layanan konseling kelompok memiliki nilai agresif tinggi dibandingkan yang sudah } \\
\text { diberi layanan. Berdasarkan penelitian tersebut, penulis menyimpulakn bahwa "Ada Pengaruh } \\
\text { Konseling Kelompok Dengan Pendekatan Behaviour Terhadap Perubahan Perilaku Agresif } \\
\text { Siswa". } \\
\text { Kata Kunci: Konseling Kelompok, Perubahan Perilaku Agresif } \\
\text { Abstract } \\
\text { This study aims to determine the effect of group counseling with a behavioral approach to } \\
\text { changes in students' aggressive behavior. In this study using the experimental method pre test-post } \\
\text { test one group design, the approach given to one group without a comparison group. The method } \\
\text { of data collection in this study by using a psychological scale (questionnaire) which was compiled } \\
\text { to reveal aggressive behavior. While the method of data analysis used Wilcoxon Test statistical } \\
\text { analysis. The results showed that there was a decrease from } 68.62 \% \text { to 56.46\% so that students } \\
\text { who had not been given counseling services had a high aggressive value compared to those who } \\
\text { had been given services. Based on these studies, the authors concluded that "There is an Influence } \\
\text { of Group Counseling with a Behavior Approach to Changes in Students' Aggressive Behavior". } \\
\text { Keywords: Group Counseling, Changes in Aggressive Behavior }\end{array}$ \\
\hline
\end{tabular}

\section{PENDAHULUAN}

Sekolah merupakan suatu lembaga yang bertugas mendidik peserta didik agar bersikap mandiri dan mempunyai tanggung jawab terhadap semua yang dilakukannya serta menjadi tumpuan dalam pembangunan negara ini. Pendidikan formal merupakan jalur pendidikan yang berstruktur dan berjenjang yang terdiri atas pendidikan dasar, pendidikan menengah, dan pendidikan tinggi (UU nomor 20 Tahun 2003 (Undang-undang Sistem Pendidikan Nasional) Bab I Pasal 1 Ayat 11). Pada dasarnya pengertian pendidikan (UU SISDIKNAS No.20 tahun 2003) adalah usaha sadar dan terencana untuk mewujudkan suasana belajar dan proses pembelajaran agar peserta didik secara aktif mengembangkan potensi dirinya untuk memiliki kekuatan spiritual keagamaan, pengendalian diri, kepribadian, kecerdasan, akhlak mulia, serta keterampilan yang diperlukan dirinya dan masyarakat.

Peserta didik adalah individu yang sedang dalam masa perkembangan, dimana mereka senang dengan penjelajahan, mencari sesuatu yang baru sebagai bahan pertimbangan dalam mencari jati 
dirinya menurut Yusuf dan Nani (2011). Dalam masa pencarian jati diri tidak jarang mereka menemukan permasalahan atau persoalan dimana permasalahan tersebut dapat mereka selesaikan sendiri yang membuat dirinya semakin kaya pengalaman hidup namun kadang permasalahan itu tidak dapat mereka selesaikan sendiri yang membuat dirinya terbebani dan menghambat dalam perkembangan dirinya biasanya mempengaruhi dalam hubungan sosialnya, mengingat manusia adalah makhluk individu dan sekaligus makhluk sosial.

Peserta didik dalam hubungan sosialnya sering mengalami permasalahan yang diwujudkan dalam perilaku agresif. Mereka sering bertengkar dengan teman, mulai dari mengejek, mengolokolok, mengancam, beradu fisik, memukul, menendang dan sebagainya. Mendukung pernyataan tersebut, menurut Krahe (2005:16) agresivitas merupakan segala bentuk perilaku yang dimaksudkan untuk menyakiti atau melukai makhluk hidup lain baik dengan verbal maupun non verbal. Perilaku tersebut merupakan bagian dari pelampiasan emosi peserta didik dimana mereka kurang memiliki daya pengendalian yang kuat sehingga untuk kepuasan hatiya mereka menyerang baik fisik maupun psikis orang lain ataupun dirinya sendiri.

Menyimak dan menyaksikan pemberitaan di media massa dan elektronik akhir-akhir ini menggambarkan bahwa tingkat agresivitas peserta didik dari waktu kewaktu semakin meningkat. Dari berbagai jenis agresivitas di sekolah maupun di luar sekolah, misalnya berkelahi, bullying, tawuran, penganiayaan, mencaci-maki teman, mencelakai, membentak guru, mencelakai guru, dan lain-lain. Secara garis besar meningkatnya perilaku agresif peserta didik akan berpengaruh terhadap kemajuan dan prestasi belajar di sekolah.

Guru Bimbingan dan Konseling (BK) di sekolah mengemukakan bahwa perilaku agresivitas peserta didik perlu di lakukan penanganan atau direduksi. Guru Bimbingan dan Konseling mengungkapkan perilaku agresivitas ini sering muncul pada peserta didik khususnya kelas VIII. Berdasarkan studi pra penelitian tersebut, peneliti menyimpulkan bahwa tingkat perilaku agresif pada peserta didik SMP Negeri 1 Jatisrono Kabupaten Wonogiri masih tinggi karena itu peneliti tertarik untuk melakukan penelitian. Oleh karena itu diperlukan penanganan dalam upaya mereduksi atau merubah perilaku agresif peserta didik. Penanganan tersebut antara lain dapat dengan pemberian layanan konseling kelompok dengan pendekatan behaviour.

Mengingat permasalahan agresivitas merupakan perilaku yang melibatkan orang lain baik pribadi maupun kelompok maka diperlukan suatu bantuan yang dapat menangani permasalahan secara kelompok, yaitu Guru Bimbingan dan Konseling. Dalam menjalankan tugasnya Guru Bimbingan dan Konseling membutuhkan media sebagai sarana yang digunakan untuk memperlancar tugasnya dalam memberikan layanan konseling kelompok kepada peserta didiknya di sekolah. 
Layanan konseling kelompok adalah layanan bimbingan dan konseling yang memungkinkan peserta didik memperoleh kesempatan untuk pembahasan dan pengentasan permasalahan yang dialaminya melalui dinamika kelompok. Dinamika kelompok ialah suasana yang hidup, yang berdenyut, yang bergerak, yang ditandai dengan adanya interaksi antar sesama anggota kelompok menurut Prayitno (2008:63). Menurut POP BK (2016:50) Konseling kelompok adalah layanan konseling yang diberikan kepada siswa dalam suasana kelompok dengan memanfaatkan dinamika kelompok untuk saling belajar dari pengalaman siswa atau masing-masing individu sehingga siswa dapat mengatasi masalah. Pelaksanaan konseling kelompok dilakukan secara bersamaan dalam satu kelompok yang membahas topik permasalahan yang sedang terjadi di lingkungan peserta didik, baik permasalahan pribadi sosial, belajar maupun karir.

Pendekatan behaviour Menurut Palmer (2011:53) pendekatan behavioral atau terapi perilaku bertujuan untuk mengubah perilaku manusia yang bisa diamati dan bisa diukur. Kegiatan ini dilakukan dengan teknik modifikasi perilaku teknik ini bermanfaat untuk mengubah perilaku yang diinginkan atau perilaku yang positif. Modifikasi perilaku dilakukan dengan cara penguatan positif (reward) dan penguatan negatif (punishment). Penguatan dilakukan dengan cara memberi pujian diri sendiri atau orang lain.

Merubah perilaku agresif peserta didik di sekolah melalui konseling kelompok dengan pendekatan behaviour memberikan pembelajaran sekaligus mengetahui sebab akibat perilaku agresif mengapa peserta didik melakukan hal-hal yang termasuk perilaku agresif. Suasana kekeluargaan konseling kelompok akan membuka pola pikir peserta didik yang awalnya sering berperilaku agresif dan penuh keikhlasan merubah perilaku agresif tersebut di sekolah maupun luar sekolah. Dengan terungkapnya sebab akibat perilaku agresif para anggota kelompok akan memberikan masukan kepada peserta didik yang bermasalah tersebut sehingga akan menimbulkan kesadaran dalam diri peserta didik.

Dalam penelitian merubah perilaku agresif peserta didik di sekolah, maka peneliti mencoba untuk menyusun penelitian bimbingan dan konseling melalui layanan konseling kelompok dengan pendekatan behaviour. Program eksperimental ini peneliti kemas melalui sebuah penelitian yang berjudul "Pengaruh Konseling Kelompok Dengan Pendekatan Behaviour Terhadap Perubahan Perilaku Agresif Siswa Kelas VIII A SMP Negeri 1 Jatisrono Kabupaten Wonogiri Tahun Pelajaran 2018/2019."

\section{METODE PENELITIAN}

Subjek Penelitian, Metode penelitian adalah suatu cara atau kegiatan dalam usaha untuk menentukan, mengumpulkan, dan mengembangkan serta menguji suatu pengetahuan dengan 
menggunakan metode-metode . Menurut Nasir (2010: 51) metode penelitian merupakan cara utama yang digunakan peneliti untuk mencapai tujuan dan menentukan jawaban atas masalah yang diajukan.

Jenis Penelitian, Dalam penelitian ini, metode yang dipergunakan adalah metode eksperimen yang bertujuan membuat paparan, gambaran secara sistematis, faktual dan akurat mengenai faktorfaktor, sifat antara fenomena untuk menjelaskan data yang digunakan waktu sekarang. Pendekatan dalam penelitian ini adalah pendekatan kuantitatif, karena penelitian ini disajikan dengan angkaangka. Hal ini sesuai dengan pendapat Suharsimi(2006:12) yang mengemukakan penelitian kuantitatif adalah pendekatan penelitian yang banyak dituntut menggunakan angka, mulai dari pengumpulan data, penafsiran data tersebut, serta penampilan hasilnya. Dalam penelitian ini menggunakan prosedur pre-test dan post-test one group design. Pada desain ini terdapat satu kelompok yang digunakan untuk penelitian, kemudian diberi pre-test untuk mengetahui keadaa awal dan diberi post-test setelah diberi layanan konseling kelompok apakah ada perbedaan sebelum dan sesudah diberi layanan.

Teknik Analisis Data, Teknik analisa data adalah proses mengorganisasikan dan mengurutkan data ke dalam pola, kategori dan satu uraian dasar sehingga dapat ditemukan tema dan rumusan hipotesis kerja seperti yang disarankan oleh data. Data yang diperoleh dan dikumpulkan dari berbagai sumber kemudian dianalisa agar dapat memahami objek yang diteliti. Analisa data dilakukan dalam proses, artinya dimulai sejak pengumpulan data dari awal secara intensif. Dalam analisa data peneliti menggunakan metode analisa kuantitatif. Adapun rumus statistik yang digunakan adalam rumus Wilcoxon.

Hasil Penelitian, Untuk mengetahui seberapa tinggi perilaku agresif siswa kelas VIII A sebelum diadakan layanan konseling kelompok, maka diadakan pembagian skala psikologi perilaku agresif dalam bentuk pre-test yang berjumlah 30 siswa kemudian dari siswa yang memiliki tingkat perilaku agresif tinggi terdapat 8 siswa. Dari 8 siswa tersebut dijadikan subjek penelitian.

Tabel 1. Hasil Pre-Test Perilaku Agresif Siswa

\begin{tabular}{clcc}
\hline No & Nama & Skor & Prosentase \\
\hline 1 & AAP & 236 & $67,04 \%$ \\
2 & ADS & 230 & $65,34 \%$ \\
3 & AM & 232 & $65,90 \%$ \\
4 & AAP & 246 & $69,88 \%$ \\
5 & DAS & 251 & $71,30 \%$ \\
6 & MYSR & 245 & $69,60 \%$ \\
7 & NDK & 241 & $69,46 \%$ \\
8 & RSA & 248 & $70,45 \%$ \\
\hline
\end{tabular}


Kemudian dari 8 siswa tersebut diberi layanan konseling kelompok pendekatan behaviour. Menurut Palmer ( 2011:53) Pendekatan behaviour atau terapi perilaku bertujuan untuk mengubah perilaku manusia yang bisa diamati dan bisa diukur. Dengan pendekatan ini diharapkan siswa mampu berpikir positif dalam menurunkan perilaku agresif melalui layanan konseling kelompok tersebut. Berikut gambar rancangan penelitian. Berikut gambar Rancangan penelitian.

\begin{tabular}{ccc}
\hline Pre-test & perlakuan & Pos-test \\
\hline $\mathrm{T} 1$ & $\mathrm{X}$ & $\mathrm{T} 2$ \\
\hline
\end{tabular}

Gambar 1. Rancangan Penelitian

Prosedur rancangan yang akan digunakan yaitu pertama, memberikan test awal (pre-test) pada T1 untuk mengukur skor rata-rata (mean) perilaku agresif siswa sebelum diberi perlakuan layanan konseling kelompok dengan pendekatan behaviour. Kedua memberikan X (perlakuan) kepada siswa dengan memberikan layanan konseling kelompok dengan pendekatan behaviour. Ketiga memberikan test akhir (post-test) pada T2 untuk mengukur skor rata-rata (mean) setelah diberi perlakuan dengan layanan konseling kelompok dengan pendekatan behaviour. Keempat membandingkan T1 dan T2 untuk menentukan ada tidaknya perbedaan sebagai akibat perlakuan X yaitu layanan konseling kelompok dengan pendekatan behaviour terhadap perilaku agresif peserta didik. Kelima menguji dengan rumus statistik untuk menentukan apakah ada pengaruh perbedaan signifikan. Keenam memberikan tafsiran/interprestasi atau memberikan hasil uji statistik.

Layanan ini dimulai bulan Juni 2019, dalam layanan konseling kelompok pertemuan ke I pada 13 Juni 2019, peneliti memberikan angket (pre-test). Pertemuan ke II pada 14 Juni 2019 peneliti memberikan treatment, pembentukan kelompok dan peralihan konseling kelompok pendekatan behaviour, serta memberikan materi. Untuk pertemuan ke III pada 20 Juni 2019 peneliti memasuki tahap inti, pengakhiran konseling kelompok pendekatan behaviour dan memberikan post-test.

Dalam kegiatan post-test ini, pengumpulan data sama dengan yang telah dilakukan sebelumnya pada pre-test. Adapun hasil skor pre-test dan post-test pada tabel 2. Hasil akhir post-test dari 8 siswa tersebut setelah melaksanakan konseling kelompok skor protentase perilaku agresif menurun. Pengujian hipotesis dalam pelaksanaan penelitian ini diolah dengan menggunakan rumus Wilcoxon bahwa hasil konsultasi tabel nilai kritis Wilcoxon (pada lampiran) dengan taraf signifikan 5\% diperoleh $\mathrm{Zt}=2,00$, maka perhitungan $\mathrm{Zo}=2,520>\mathrm{Zt}=2,00$. Dengan demikian untuk taraf signifikasi $5 \%$ perhitungannya Zo > Zt. Maka dengan layanan konseling kelompok dengan pendekatan behaviour tingkat agresif siswa menurun. 
Tabel 2. Hasil pre-test dan post-test

\begin{tabular}{llcc}
\hline \multirow{2}{*}{ No } & \multirow{2}{*}{ Nama } & Pre-test & Post-test \\
\cline { 3 - 4 } & & Skor & Skor \\
\hline 1 & AAP & 236 & 233 \\
2 & ADS & 230 & 226 \\
3 & AM & 232 & 218 \\
4 & AAP & 246 & 150 \\
5 & DAS & 251 & 198 \\
6 & MYSR & 245 & 154 \\
7 & NDK & 241 & 219 \\
8 & RSA & 248 & 192 \\
\hline
\end{tabular}

\section{PEMBAHASAN}

Berdasarkan hasil pengumpulan dan pengolahan data penelitian menunjukan adanya pengaruh layanan konseling kelompok terhadap perilaku agresif pada siswa kelas VIII A Sekolah Menengah Pertama Negeri 1 Jatisrono setelah diberi layanan konseling kelompok.

Oleh karena itu, dalam penelitian ini hipotesis berbunyi "ada pengaruh layanan konseling kelompok terhadap perubahan perilaku agresif siswa kelas VIII A Sekolah Menengah Pertama Negeri 1 Jatisrono tahubn pelajaran 2018/2019" dapat diterima kebenarannya.

\section{KESIMPULAN}

Berdasarkan hasil penelitian, kesimpulan dalam penelitian ini bahwa konsultasi tabel nilai kritis Wilcoxon dengan taraf signifikan 5\% diperoleh $\mathrm{Zt}=2,00$, maka perhitungan $\mathrm{Zo}=2,520>\mathrm{Zt}=2,00$. Dengan demikian untuk taraf signifikasi $5 \%$ perhitungannya $\mathrm{Zo}>\mathrm{Zt}$. Karena perhitungan $\mathrm{Zo}>\mathrm{Zt}$ maka Ha ditolak dan Ho diterima. Jadi dari hasil analisis tersebut dapat disimpulkan bahwa ada pengaruh layanan konseling kelompok terhadap perilaku agresif siswa kelas VIII A Sekolah Menengah Pertama Negeri 1 Jatisrono tahun pelajaran 2018/2019. 


\section{DAFTAR PUSTAKA}

Anantasari. (2006). Menyikapi Perilaku Agresif Anak. Yogyakarta: Kanisius

Arends, R. (2008). Learning to Each. Belajar untuk Mengajar. Yogyakarta: Pustaka Belajar

Bandura, A. (2009). Growing centrality of self regulation in health promotion and disease prevention.European Health Psychologist. Jakarta: Erlangga

Baron, R., Byrne, D. (2005). Psikologi Sosial: Jilid 2. Jakarta: Erlangga

Bower. (2008). Perilaku Agresif. Jakarta:Erlangga

Daviddoff, L. (2014). Psikologi Suatu Pengantar: Jilid 2. Jakarta: Erlangga

Komalasi, G. (2011). Teori dan Teknik Konseling. Jakarta Barat: PT Indeks

Hartono, Soedarmadji, B. (2012). Psikologi Konseling Edisi Revisi. Jakarta: Kencana Prenada Media Group

Ismail. (2011). Penelitian Pendidikan. Sukoharjo: Univet Bantara Press. Kamus Besar Bahasa Indonesia.

Kemendikbud. (2016). Panduan Operasional Penyelenggaraan Bimbingan dan Konseling. Jakarta: Balai Pustaka

Kemendiknas. (1995). Kamus Besar Bahasa Indonesia. Jakarta: Balai Pustaka

Kemendiknas. (2005). Kamus Besar Bahasa Indonesia. Jakarta: Balai Pustaka

Krahe, B. (2005). Perilaku Agresif. Yogyakarta: Pustaka Belajar

Palmer, S. (2011). Konseling dan Psikoterapi. Yogyakarta. Pustaka Belajar

Prayitno. (1995). Dasar bimbingan dan Konseling. Jakarta: Rineka Cipta

Prayitno. (2005). Dasar-dasar Bimbingan dan Konseling. Jakarta: Rineka Cipta

Prayitno. (2008). Layanan Bimbingan dan Konseling Kelompok (Dasar dan Profil). Jakarta. Ghalia Indonesia

Arends, R. (2008). Learning to Each. Belajar untuk Mengajar. Yogyakarta: Pustaka Belajar

Sudjana. (2002). Penelitian Kuantitatif. Bandung: Tarsito

Sudjana. (2012). Metode Statistika. Bandung: Tarsito

Sugiyono. (2001). Metode Penelitian. Bandung: CV Alfa Beta

Sugiyono. (2016). Metodologi Penelitian Kuantitatif, Kualitatif, dan R\&D. Bandung: CV Alfa Beta

Suharsimi, A. (2006). Prosedur Penelitian Suatu Pendekatan Praktek. Jakarta: Rineka Cipta

Suharsimi, A. (2013. Prosedur Penelitian Suatu Pendekatan Praktek. Jakarta: Rineka Cipta

Tohirin. (2007). Bimbingan dan Konseling di Sekolah dan Madrasah(Berbasis Integrasi). Jakarta: Raja Grafindo Persada

Winkel, W., Hastuti, S. (2004). Bimbingan dan Konseling di Institusi Pendidikan. Yogyakarta: Media Abadi

Yusuf, S., Nani, M. (2011). Perkembangan Peserta Didik. Jakarta: Raja Grafindo Persada 